\title{
GMR
}

\section{Correlation between serum level of chemokine (C-C motif) ligand 18 and poor prognosis in breast cancer}

\author{
J.H. Sun ${ }^{1}$ N. Fan ${ }^{2}$ and Y. Zhang ${ }^{1}$ \\ ${ }^{1}$ Xianyang Hospital of Yan'an University Clinical Laboratory, Xianyang, China \\ ${ }^{2}$ The First People's Hospital of Xianyang, Xianyang, China \\ Corresponding author: J.H. Sun \\ E-mail: sunjihong_1@163.com \\ Genet. Mol. Res. 15 (3): gmr.15038632 \\ Received March 21, 2016 \\ Accepted May 5, 2016 \\ Published September 9, 2016 \\ DOI http://dx.doi.org/10.4238/gmr.15038632
}

Copyright (C) 2016 The Authors. This is an open-access article distributed under the terms of the Creative Commons Attribution ShareAlike (CC BY-SA) 4.0 License.

\begin{abstract}
In this study, we investigated the correlation between serum chemokine (C-C motif) ligand 18 (CCL-18) and the prognosis as well as clinical characteristics of breast cancer. Blood samples from 207 breast cancer patients, 126 individuals with benign breast tumors, and 93 healthy women were collected. Serum CCL-18 expression was detected by enzyme-linked immunosorbent assay. Mann-Whitney's U tests were carried out to analyze the relationship between serum CCL18 and clinicopathological variables. The Kaplan-Meier method was used to evaluate the overall survival (OS), whereas differences between groups were analyzed by log-rank tests. The COX proportional hazard regression model was used to determine the association between clinicopathological characteristics and survival. We found that serum CCL-18 was significantly higher in breast cancer patients $(290.06 \pm$ $89.52 \mathrm{pg} / \mathrm{mL}$ ) as compared to that in individuals with benign tumors $(170.14 \pm 26.57 \mathrm{pg} / \mathrm{mL})$ or healthy women $(119.36 \pm 38.77 \mathrm{pg} / \mathrm{mL})(\mathrm{P}$
\end{abstract}


$<0.05)$. Serum CCL-18 was correlated with clinical cancer stages $(\mathrm{P}$ $=0.007)$, and was associated with advanced cancer stage $(\mathrm{P}<0.05)$. The 5-year OS rate of breast cancer patients with high serum CCL18 was $35.9 \%(\mathrm{HR}=3.908,95 \% \mathrm{CI}=2.546-12.090, \mathrm{P}<0.05)$, which was significantly lower as compared to that for patients with low serum CCL-18 (85.5\%). Based on our results, we conclude that CCL-18 is a prognostic biomarker in patients with advanced breast cancer in Chinese patients.

Key words: Breast cancer; Prognosis; CCL-8; Serum; Biomarker

\section{INTRODUCTION}

Breast cancer is one of the most common cancers in women worldwide. Approximately 400,000 women die from breast cancer every year, and its rate of incidence is rising (Parkin et al., 2005). Jemal et al. (2011) found that $56 \%$ of breast cancer cases occur in areas within developing countries, such as the Yanan Shanxi region of China. The development of breast cancer is associated with genetic predisposition, environmental pollution, and factors that affect the cell's microenvironment, such as tumor necrosis factors, interleukins, and inflammatory factors (Feng et al., 2009). According to Harris et al. (2003), inflammatory factors participate in the pathogenesis of breast cancer, while anti-inflammatory factors could reduce the incidence and recurrence rate of this disease.

Chemokine C-C motif ligand 18 (CCL-18), an inflammatory factor, was identified as a biomarker in gastric and ovarian cancers (Schutyser et al., 2002; Leung et al., 2004). In addition, it has been clinically used for the identification, treatment, and prognosis prediction of cancers. CCL-18 is mainly secreted by macrophages and dendritic cells, and regulates the immune status by promoting angiogenesis and leukocyte trafficking (Schutyser et al., 2005). It has been suggested that CCL-18 is not only associated with acute lymphoblastic leukemia, gastric cancer, breast cancer, and ovarian cancer, but also predicts poor disease prognosis in malignant tumors (Schutyser et al., 2002; Struyf et al., 2003; Leung et al., 2004; Chen et al., 2011).

Various studies have been conducted to examine the association between serum CCL-18 levels and disease prognosis in colon and gastric cancers. However, the association between CCL18 and breast cancer prognosis in Chinese patients is still not clear. Furthermore, the relationship between CCL-18 and sensitivity to chemotherapies in malignant tumor is still an area of active investigation. In our study, we compared serum CCL-18 levels between breast cancer patients, women with benign tumors, and healthy women. We aimed to determine the association between serum CCL-18 levels and breast cancer in the Yanan Shanxi region of China.

\section{MATERIAL AND METHODS}

\section{Patients}

We recruited 207 breast cancer patients (median age $=47$ ) and 126 women with benign breast tumors (median age $=45$ ), who were hospitalized in the Yan'an University Hospital of Xianyang between January 1, 2005 to December 31, 2010.

Breast cancer was confirmed in the 207 recruited patients according to previously

Genetics and Molecular Research 15 (3): gmr.15038632 
described diagnostic criteria (Cedolini et al., 2014). We included 23 patients with carcinoma in situ, 158 with invasive ductal carcinoma, 12 with invasive lobular carcinoma, 11 with mucinous carcinoma, and 3 with inflammatory carcinoma. There were 69 cases of stage II cancer, 86 cases of stage III cancer, and 52 cases with stage IV breast cancer. The clinicopathological characteristics of all patients are listed in Table 1.

Of the 126 women diagnosed with benign breast tumors, 76 displayed breast fibroadenoma, 18 had intraductal papilloma, 15 had fibrocystic disease of breast, 9 had mastitis, and 8 patients were affected with juvenile fibroadenoma. Lastly, 93 healthy women were included in the study as control.

All subjects were without history of any other types of cancers, and underwent clinical examinations, including breast CT scans, breast ultrasounds, breast molybdenum target X-rays, and nuclear magnetic resonance. There were no significant differences among breast cancer patients, those with benign tumor, and healthy women in terms of age and smoking history. Diagnosis was performed by two pathologists, and agreement was reached for each case. The study was approved by the medical Ethics Committee of Yan'an University Hospital of Xianyang. Written informed consent was obtained from all subjects prior to study enrollment.

\begin{tabular}{|c|c|c|c|c|c|}
\hline \multicolumn{2}{|l|}{ Characters } & \multirow{3}{*}{$\begin{array}{c}\text { Cases (N) } \\
41\end{array}$} & \multicolumn{2}{|c|}{ Serum CCL-18 } & \multirow[t]{2}{*}{ P value } \\
\hline & & & High & Low & \\
\hline \multirow[t]{3}{*}{ Age } & $<50$ & & 30 & 11 & \multirow[t]{3}{*}{0.73} \\
\hline & $50-70$ & 97 & 77 & 20 & \\
\hline & $>70$ & 69 & 47 & 22 & \\
\hline \multirow[t]{3}{*}{ Smoking history } & \begin{tabular}{|l|} 
Current \\
\end{tabular} & 86 & 57 & 29 & \multirow[t]{3}{*}{0.14} \\
\hline & Former & 79 & 58 & 21 & \\
\hline & Never & 42 & 33 & 9 & \\
\hline \multirow[t]{4}{*}{ Stage } & I & 0 & 0 & 0 & \multirow[t]{4}{*}{0.007} \\
\hline & II & 69 & 51 & 18 & \\
\hline & III & 88 & 72 & 16 & \\
\hline & IV & 50 & 46 & 4 & \\
\hline
\end{tabular}

\section{Blood samples collection}

Blood samples of all the subjects were collected at the time of diagnosis prior to surgical resection, radiation, or chemotherapy. Subjects were fasted prior to blood withdrawal at 6 a.m. Serum was separated and stored at $-80^{\circ} \mathrm{C}$.

\section{Serum CCL-18 detection by ELISA}

Serum CCL-18 was detected by enzyme-linked immunosorbent assay (ELISA) using the Human CCL-18 ELISA kit (Sigma-Aldrich Co. LLC., Shanghai, China) according to manufacturer specification. The optical density (OD) at $450 \mathrm{~nm}$ was determined by an enzyme-labeling measuring instrument (Promega Biotech Co., Ltd. Beijing, China). Standard curves were established with $\mathrm{OD}_{450}$ on the Y-axis and concentration of the standard on the $\mathrm{X}$-axis; serum CCL-18 levels were extrapolated using the standard curve.

Genetics and Molecular Research 15 (3): gmr.15038632 


\section{Statistical analysis}

All the data were analyzed by the SPSS 13.0 software (SPSS, IBM, Chicago, IL, USA). Data are reported as means \pm standard deviation (SD). The Mann-Whitney U tests were used to analyze the relationship between serum CCL-18 and clinicopathological variables. The Kaplan-Meier method was used to evaluate the overall survival (OS) of patients, and betweengroup differences were analyzed via log-rank tests. The Cox proportional hazard regression model was used to determine the association between clinicopathological characteristics and survival. Statistical significance was denoted by $\mathrm{P}<0.05$.

\section{RESULTS}

\section{Serum CCL-18 expression and its association with clinicopathological features}

Serum CCL-18 expression in each group is shown in Table 2. Serum CCL-18 expression in breast cancer patients was $290.06 \pm 89.52 \mathrm{pg} / \mathrm{mL}$, which was significantly higher than in those with benign tumors $(170.14 \pm 26.57 \mathrm{pg} / \mathrm{mL})$ and healthy individuals $(119.36 \pm$ $38.77 \mathrm{pg} / \mathrm{mL})$.

In addition, serum CCL-18 level in TNM stage IV breast cancer patients $(392.37 \pm$ $80.35 \mathrm{pg} / \mathrm{mL})$ was higher as compared with that in TNM stage III $(280.91 \pm 77.25 \mathrm{pg} / \mathrm{mL})$ and stage II $(198.73 \pm 47.89 \mathrm{pg} / \mathrm{mL})$ patients.

The average serum CCL-18 concentration $(290.06 \pm 89.52 \mathrm{pg} / \mathrm{mL})$ was set as a cutoff value for categorization. Breast cancer patients with serum CCL-18 levels lower than the average value were denoted as having low expression, while those with serum CCL$18>290.06 \pm 89.52 \mathrm{pg} / \mathrm{mL}$ were denoted as having high expression. As shown in Table 1, high serum CCL-18 expression was correlated with TNM stages $(\mathrm{P}=0.007)$. However, no correlation was found between serum CCL-18 level and age or smoking history.

Table 2. Serum CCL-18 breast cancer patients, women with benign tumor, and controls ( $\mathrm{pg} / \mathrm{mL})$.

\begin{tabular}{|c|c|c|c|c|c|}
\hline & \multicolumn{5}{|c|}{ Serum CCL-18 expression (means \pm SD) } \\
\hline & \multicolumn{3}{|c|}{ Breast cancer women $(\mathrm{N}=207)$} & Benign tumor women $(\mathrm{N}=126)$ & Healthy women $(\mathrm{N}=93)$ \\
\hline & & TNM stage & \multirow{4}{*}{$\begin{array}{c}\text { Average } \\
290.06 \pm 89.52\end{array}$} & \multirow[t]{4}{*}{$170.14 \pm 26.57^{*}$} & \multirow[t]{4}{*}{$119.36 \pm 38.77^{* \#}$} \\
\hline \multirow{3}{*}{ Concentration } & II & $198.73 \pm 47.89$ & & & \\
\hline & III & $280.91 \pm 77.25^{\&}$ & & & \\
\hline & IV & $392.37 \pm 80.35^{\& s}$ & & & \\
\hline
\end{tabular}

*Compared to breast cancer patients, $\mathrm{P}<0.05$; ${ }^{*}$ compared to women with benign tumor, $\mathrm{P}<0.05 ;{ }^{*}$ compared to patients at TNM stage II, $\mathrm{P}<0.05 ;{ }^{\text {s }}$ compared to TNM stage III, $\mathrm{P}<0.05$.

\section{Serum CCL-18 expression and disease prognosis of breast cancer patients}

The results of the Kaplan-Meier analysis showed that the 5-year OS rate of breast cancer patients with high serum CCL-18 level was $35.9 \%$, which was lower as compared with that of low serum CCL-18 (85.5\%) patients. As shown in Table 3, the result of multivariate Cox model showed that serum CCL-18 expression was an independent prognostic factor for poor 5 -year OS (hazard ratio $=3.908,95 \%$ confidence interval $=2.546-12.090, \mathrm{P}=0.024$ ) in breast cancer patients.

Genetics and Molecular Research 15 (3): gmr.15038632 
Table 3. Multivariate analyses of prognostic factors for breast cancer $(\mathrm{N}=207)$.

\begin{tabular}{l|c|c|c}
\hline Characters & HR & $95 \%$ CI & P value \\
\hline Age & 0.908 & $0.296-1.735$ & 0.489 \\
\hline Smoking history & 1.738 & $0.775-3.980$ & 0.112 \\
\hline TNM stages & 4.506 & $2.506-8.875$ & 0.019 \\
\hline Serum CCL-18 & 3.908 & $2.546-12.090$ & 0.024 \\
\hline
\end{tabular}

$\mathrm{HR}=$ hazard ratio; $\mathrm{CI}=$ confidence interval.

\section{DISCUSSION}

The CCL-18 gene, which is located on 17q11.2, encodes a cytokine that is secreted by various cells such as nucleus cells, macrophages, T cells, B cells, dendritic cells, hemopoietic progenitor cells, fibroblasts, and tumor cell. CCL-18 acts through autocrine and paracrine signaling, and participates in immunologic and inflammatory processes (Urquidi et al., 2012). Previous studies have shown that CCL-18 also has the ability affect tumorigenesis, and can affect the grade and prognosis of ovarian, colon, and gastric cancers. In the treatment of breast cancer with carcinoma-associated fibroblast (CAF) regimen, Peng et al. (2013) found that breast cancer cells co-cultured with CAF resulted in increased CCL-18 secretion, which promoted the invasion and metastasis of breast cancer cells. Furthermore, Nariţa et al. (2011) found that breast cancer patients with elevated serum CCL-18 levels were associated with poor disease prognosis. In the current study, we investigated the association between serum CCL18 and breast cancer in order to determine whether CCL-18 is a biomarker for poor disease prognosis in the Yanan Shanxi region of China. We found that serum CCL-18 level was higher in breast cancer patients as compared with that of healthy women and individuals with benign tumors. This result suggested that serum CCL-18 may be a biomarker for breast cancer, and may participate in tumorigenesis. Furthermore, we found that serum CCL-18 levels differed among breast cancer patients at different TNM stages; serum CCL-18 was significantly higher in stage IV patients as compared to that in stages II and III patients. We suggest that elevated CCL-18 level can be used as a biomarker for advanced breast cancer. Notably, Leung et al. (2004) reported that serum CCL-18 was negatively correlated with clinical cancer stages. It is possible that the role of CCL-18 varies due to different immunological mechanisms in different cancers (Chen et al., 2011). As expected, we did not find any association between serum CCL-18 level and age or smoking history.

Previous studies have also shown that serum CCL-18 was associated with tumorigenesis, and its expression was correlated with TNM staging, but not metastasis, in primary lung cancer patients (Plönes et al., 2012). An association between CCL-18 and OS rate was also found in pancreatic cancer. In our study, we found that the 5-year OS rate was lower in breast cancer patients with high serum CCL-18 expression as compared to those with low serum CCL-18 expression. This further confirmed that high serum CCL-18 is an indicator of poor prognosis in breast cancer.

CCL-18 is secreted by tumor-associated macrophages (TAMs), which can produce many factors such as IL-10 (Sica et al., 2000; Struyf et al., 2003). In children with acute lymphoblastic leukemia, serum CCL-18 expression was shown to be increased, which suggested that CCL-18 might also be a predictor of acute lymphoblastic leukemia in children (Struyf et al., 2003). According to Chen et al. (2011), the M2 subset of TAM is increased in the tumor cell microenvironment, which results in increased CCL-18 secretion. It is therefore

Genetics and Molecular Research 15 (3): gmr.15038632 
possible that CCL-18 can play an important role in modulating the microenvironment of breast cancer cells, and promote the development and invasion of breast tumors.

In conclusion, our results indicate that serum CCL-18 is overexpressed in breast cancer patients, and may be a biomarker for poor prognosis in advanced breast cancer among the Chinese population. However, further studies need to be carried out to investigate the association between serum CCL-18 and tumor proliferation, metastasis, invasion, as well as other clinicopathological characteristics. In addition, the underlying mechanisms behind increased serum CCL-18 in breast cancer patients still need further clarification. A greater understanding of the role of serum CCL-18 in breast cancers may lead to alternative treatments for this disease.

\section{Conflicts of interest}

The authors declare no conflict of interest.

\section{REFERENCES}

Cedolini C, Bertozzi S, Londero AP, Bernardi S, et al. (2014). Type of breast cancer diagnosis, screening, and survival. Clin. Breast Cancer 14: 235-240. http://dx.doi.org/10.1016/j.clbc.2014.02.004

Chen J, Yao Y, Gong C, Yu F, et al. (2011). CCL18 from tumor-associated macrophages promotes breast cancer metastasis via PITPNM3. Cancer Cell 19: 541-55.http://dx.doi.org/10.1016/j.ccr.2011.02.006

Feng LY, Ou ZL, Wu FY, Shen ZZ, et al. (2009). Involvement of a novel chemokine decoy receptor CCX-CKR in breast cancer growth, metastasis and patient survival. Clin. Cancer Res. 15: 2962-2970. http://dx.doi.org/10.1158/10780432.CCR-08-2495

Harris RE, Chlebowski RT, Jackson RD, Frid DJ, et al. (2003). Breast cancer and nonsteroidal anti-inflammatory drugs: prospective results from the Women's Health Initiative. Cancer Res. 63: 6096-6101.

Jemal A, Bray F, Center MM, Ferlay J, et al. (2011). Global cancer statistics. Ca- Cancer J. Clin. 61: 69-90. http://dx.doi. org $/ 10.3322 /$ caac. 20107

Leung SY, Yuen ST, Chu KM, Mathy JA, et al. (2004). Expression profiling identifies chemokine (C-C motif) ligand 18 as an independent prognostic indicator in gastric cancer. Gastroenterology 127: 457-469. http://dx.doi.org/10.1053/j. gastro.2004.05.031

Nariţa D, Seclaman E, Ursoniu S, Ilina R, et al. (2011). Expression of CCL18 and interleukin-6 in the plasma of breast cancer patients as compared with benign tumor patients and healthy controls. Rom. J. Morphol. Embryol. 52: 1261-1267.

Parkin DM, Bray F, Ferlay J and Pisani P (2005). Global cancer statistics, 2002. Ca- Cancer J. Clin. 55: 74-108. http:// dx.doi.org/10.3322/canjclin.55.2.74

Peng Q, Zhao L, Hou Y, Sun Y, et al. (2013). Biological characteristics and genetic heterogeneity between carcinomaassociated fibroblasts and their paired normal fibroblasts in human breast cancer. PLoS One 8: e60321. http://dx.doi. org/10.1371/journal.pone.0060321

Plönes T, Krohn A, Burger M, Veelken H, et al. (2012). Serum level of CC-chemokine ligand 18 is increased in patients with non-small-cell lung cancer and correlates with survival time in adenocarcinomas. PLoS One 7: e41746. http:// dx.doi.org/10.1371/journal.pone.0041746

Sica A, Saccani A, Bottazzi B, Polentarutti N, et al. (2000). Autocrine production of IL-10 mediates defective IL-12 production and NF-kappa B activation in tumor-associated macrophages. J. Immunol. 164: 762-767. http://dx.doi. org/10.4049/jimmunol.164.2.762

Schutyser E, Struyf S, Proost P, Opdenakker G, et al. (2002). Identification of biologically active chemokine isoforms from ascitic fluid and elevated levels of CCL18/pulmonary and activation-regulated chemokine in ovarian carcinoma. $J$. Biol. Chem. 277: 24584-24593. http://dx.doi.org/10.1074/jbc.M112275200

Schutyser E, Richmond A and Van Damme J (2005). Involvement of CC chemokine ligand 18 (CCL18) in normal and pathological processes. J. Leukocyte Biol. 78: 14-26. http://dx.doi.org/10.1189/jlb.1204712

Struyf S, Schutyser E, Gouwy M, Gijsbers K, et al. (2003). PARC/CCL18 is a plasma CC chemokine with increased levels in childhood acute lymphoblastic leukemia. Am. J. Pathol. 163: 2065-2075. http://dx.doi.org/10.1016/S00029440(10)63564-X

Urquidi V, Kim J, Chang M, Dai Y, et al. (2012). CCL18 in a multiplex urine-based assay for the detection of bladder cancer. PLoS One 7: e37797. http://dx.doi.org/10.1371/journal.pone.0037797

Genetics and Molecular Research 15 (3): gmr.15038632 